\title{
POLITICAL ANTHROPOLOGY AND CIVIL SERVICE REFORM: PROSPECTS AND LIMITS*
}

\author{
R. A. W. Rhodes \\ Professor of Government, University of Southampton, UK; and \\ Professor of Government and Public Policy, Griffith University, \\ Australia.
}

\section{Address for correspondence:}

School of Social Sciences

University of Southampton

Southampton

SO17 1BJ

United Kingdom

E-mail: r. a.w.rhodes@ soton.ac.uk

\section{INTRODUCTION}

A core question for this special issue on '40 Years of Policy \& Politics' is how to use experience to inform future policy. Over the years, the journal has returned frequently to the topic of public sector and public management reform. So, this article addresses matters of central concern to the journal in its anniversary year. Specifically, I ask two questions. What lessons about reforming the British civil service can be learnt from using observational methods to study British government departments? What are the strengths and weaknesses of such an approach in the reform of public administration?

Both questions are unusual in political science. First, observation is not a common research tool because of such obstacles as the addiction to secrecy of British government. Thus, Fine et al 2009 cite no studies by political scientists in their survey of organizational

\footnotetext{
*To be published in Policy \& Politics Volume 41, Number 3, October 2013.
} 
ethnography (and see Rhodes 2013 for citation and discussion). Second, those relatives of observation such as action research and organizational learning (Arygris and Schon 1996) are said to have limited applicability in civil service reform because these approaches are compromised by the political environment (Commons 2004, 36-38).

As Geertz $(1983,21)$ points out, 'there has been an enormous amount of genre mixing in intellectual life' as 'social scientists have turned away from a laws and instances ideal of explanation towards a cases and interpretations one' and towards 'analogies drawn from the humanities'. Examples of such analogies include social life as game, as drama, and as text. There is a specific problem for public administration. As we blur genres, we bring 'the social technologist notion of what a social scientist is ... into question' (Geertz 1983, 35). Rather, the task becomes to recover the meaning of games, dramas and texts and to tease out their consequences. So, this article blurs genres, combining political science and cultural anthropology to explore civil service reform. Then, confronting the 'social technologist' issue, I ask, 'what lessons can public administration drawn from this research'? Can recovering stories provide lessons for the would-be reformer?

The article has three sections. The first, section provides a brief account of the main characteristics of public sector reform over the past decade; namely, evidence-based policy making, managerialism, and choice. The second section compares the reform proposals with the fieldwork reported in Rhodes (2011) and draws lessons for would-be reformers. I use five axioms for ease of exposition: coping and the appearance of rule, not strategic planning; institutional memory, not internal structures; storytelling, not evidence based policy; contending traditions and stories, not managerialism; the politics of implementation, not topdown innovation and control. The final section discusses the strengths and weaknesses of my approach both in the study of public administration and for public sector reform. I argue that 
attempts to impose private sector management beliefs and techniques to increase the economy, efficiency and effectiveness have had at best variable success. I conclude we do not need more managerialism but a different approach to reform that recognizes the centrality of organizational traditions and storytelling.

\section{THE REFORMS}

This section suggests that the reforms of the civil service proposed by both think-tanks and the government over the past decade are pervaded by beliefs in the instrumental rationality of evidence-based policymaking, managerialism, and economic choice. These ideas are the shared, almost tacit, knowledge of contributors to the continuing debate about public sector reform. I will be brief because my remarks verge on the obvious.

\section{Evidenced-based policymaking}

At the heart of the Cabinet Office's (1999) professional policy making model is a belief in evidence based policy making. For example, their model 'uses the best available evidence from a wide range of sources'; and 'learns from experience of what works and what doesn't' through systematic evaluation (Cabinet Office 1999, para. 2.11). By July 2011, when the Coalition government launched its Open Public Services White Paper (Cm 8145, 2011), little had changed. Despite claims that 'something very big and different is happening with this White Paper' (Cameron 2011), most observers saw only more of the same. The emphasis fell on 'building on evidence of what works'. Phrases like 'sound evidence base' 'what works' and 'robust evidence' abound. Departments would need a 'clearer understanding of what their priorities are' and need 'to ensure administrative resources match Government policy priorities' so the Government can get 'value for taxpayers' money in delivering its 
objectives (Cabinet Office 2012, 14, 16 and 20). The instrumental rationality of evidencebased policymaking is alive and well and at the heart of the Coalition's reform agenda. Moreover, this view of the policymaking process is widely shared inside and outside government (see, for example: Better Government Institute 2010; Bullock, Mountford and Stanley 2001; Davies, Nutley and Smith 2000; Institute for Government 2010; Lodge and Rogers 2006; Mulgan 2009; National Audit Office 2001; Regulatory Policy Institute 2009; and Sanderson 2002).

\section{Managerialism}

Managerialism has a long history which cannot be retold here (see: Pollitt 1993). In brief, it is a set of inherited beliefs about how private sector management techniques would increase the economy, efficiency and effectiveness - the 3Es - of the public sector. Initially the beliefs focused on managerialism or hands-on, professional management; explicit standards and measures of performance; managing by results; and value for money. Subsequently, it also embraced marketization or neo-liberal beliefs about competition and markets. It introduced ideas about restructuring the incentive structures of public service provision through contracting-out, quasimarkets; and consumer choice. New Labour introduced a third strand to managerialism with its service delivery agenda.

For my purpose, I need to show only that such reform persists (and for a review of the 2000s see Public Administration Select Committee (PASC 2009). The core concern for decades has been better performance management whether called accountable management or management-by-objectives. Only the labelling has changed. So, even today, 'effective performance assessment within government helps to identify how well public organizations are meeting their objectives, as well as highlighting where improvements could be made' 
(PASC 2009, 3; see also Cabinet Office 2012, 28-29; PASC 2003; Better Government Institute (BGI) 2010, 33).

\section{Delivery and choice}

The general principles informing the delivery agenda were outlined by Michael Barber, the Prime Minister's former Chief Adviser on Delivery in his comments about education:

Essentially it's about creating different forms of a quasi-market in public services, exploiting the power of choice, competition, transparency and incentives. (Interview with Michael Barber 13 January 2006; see also Barber 2007, chapter 3; and PASC 2005).

Despite the brouhaha about its novelty, the Coalition government also focused on service delivery and customer. Although evidence-based policy making and managerialism remain prominent strands in the Coalition's reform proposals, choice is the first principle of the reforms; 'wherever possible we are increasing choice by giving people direct control over the services they use' (Cameron 2011). The White Paper claims that 'the old centralized approach to public service delivery is broken', so 'wherever possible we will increase choice' and 'power will be decentralized to the lowest appropriate level'. Such choice will only happen if service delivery is 'opened up to a range of providers of different sizes and different sectors' (Cm 8145, 2011, 8-9). Choice, decentralization and diversity of providers are three core tenets of the proposed reforms.

All the ideas about evidence-based policymaking, managerialism and choice are part of the vocabulary of senior civil servants. For example, O'Donnell (2012), former Head of the Home Civil Service, includes clear objectives, objective evaluation and honouring the evidence among his ten commandments of good policymaking. As the Regulatory Policy Institute (2009, para 31) observes, 'every suggestion' in the 'numberless' reports on civil service reform are 'a version of the same, how better to manage an ever more centralized 
state'. In sum, instrumental rationality, managerialism and choice rule, and it is not OK. It adds up to the 'Civil Service reform syndrome', which comprises:

ideas like total quality management, red tape bonfires, better consultation, risk management, competency, evidence-based policy, joined-up government, delivery leadership, and now better policymaking. Such initiatives come and go, overlap and ignore each other, leaving behind residues of varying size and style (Hood and Lodge 2007, 59).

The syndrome persists because the assumptions behind reforms are not fit for public sector purpose.

\section{LESSONS}

Rhodes (2011) seeks to understand the ways in which the political and administrative elites of British central government departments made sense of their worlds. It provides 'thick descriptions', or my constructions of their constructions of what they are up to (Geertz 1973), through an analysis of their beliefs and everyday practices. As Law $(1994,263)$ observes, outsiders studying an organization 'are no more able to offer a single and coherent account of the way in which it orders itself' than its managers. So, just as civil servants seek to domesticate the everyday life of their minister, I seek to domesticate the many competing beliefs and practices of the departments.

\section{Methods}

I draw on three sources of information: 'the pattern of practice, talk, and considered writing' (Oakeshott 1996, x). On practice, I observed the office of two ministers and three 
permanent secretaries for two days each. I also shadowed two ministers and three permanent secretaries for five working days each. On talk, I had repeat interviews with: ten permanent secretaries, five secretaries of state, three ministers, and twenty other officials. On considered writing, I had newspaper reports, copies of speeches and public lectures, and committee and other papers relevant to the meetings I observed.

My interviews and fieldwork observations were for citation but not for attribution without the interviewee's permission. I studied three ministries: the Department of Trade and Industry (DTI), the Department for Education and Skills (DfES), and the Department for Environment, Food \& Rural Affairs (DEFRA). I conducted the interviews in 2002. The fieldwork was carried out in 2003. There were several repeat interviews and occasional visits in 2004. Following the established practice of latter-day ethnographers, I undertook 'yo-yo fieldwork'. I repeatedly went back and forth, in and out of the field (Wulff 2002, 117). I also went to more than one fieldwork site because I was 'studying through'; that is, following events through the 'webs and relations between actors, institutions and discourses across time and space' (Shore and Wright 1997, 14). The research methods and the findings are reported in detail in Rhodes (2011).

\section{Axioms}

Political scientists can aspire to 'plausible conjectures'; that is, to making general statements which are plausible because they rest on good reasons and the reasons are good because they are inferred from relevant information (paraphrased from Boudon 1993). This section draws out my conjectures or lessons from the fieldwork and asks whether the various reform proposals blend with the everyday beliefs and practices of civil servants and their ministers. I use five axioms for clarity of exposition: 
$>\quad$ Institutional memory, not internal structures

$>\quad$ Storytelling, not evidence based policy

$>\quad$ Contending traditions and stories, not just managerialism

$>\quad$ The politics of implementation, not top down innovation and control.

I accept that these axioms oversimplify but I want to dramatize the difference between rational and storytelling reforms.

\section{Coping and the appearance of rule, not strategic planning}

At the top of government departments we find a class of political-administrators, not politicians or administrators. They live in a shared world. Their priority and their skills are about surviving in a world of rude surprises. The goal is willed ordinariness. They do not need more risk. They are adrift in an ocean of storms. Only reformers have the luxury of choosing which challenge they will respond to. Ministers and permanent secretaries have to juggle the contradictory demands posed by recurring dilemmas. They must appear to be in control. I incline to Weiss's (1980) notions of decision accretion and knowledge creep. Thus, policy emerges from routine and builds like a coral reef. Similarly, rational policy analysis creeps into the decision process almost by osmosis, by becoming part of the zeitgeist, rather than overt deliberation. Civil service reform is not, therefore, a matter of solving specific problems but of managing unfolding dilemmas and their inevitable unintended consequences. There is no solution but a succession of solutions to problems which are contested and redefined as they are 'solved'. This analysis is an anathema to the would-be reformers of the previous section, but it is the fate of their rational schemes. 
Strategic planning is a clumsy add-on to this world. Its timescale is too long. Its concerns too far removed from the everyday life concerns of its short-stay incumbents. The demands of political accountability and the media spotlight do not pay attention to strategic priorities. Relatively trivial problems of implementation can threaten a minister's career. Finally, the call for clear roles and responsibilities, for objectives and targets, is an idealized rational model of policymaking largely removed from the messy reality of public policy making.

The limits to the rational model of policy making have been spelt out so often, they need no repetition. Crucially, as practiced, rational analysis is retrospective not prospective. It is used to justify decisions already taken by other means and for other reasons. And the other reasons are usually political ones. There is no obvious reason to prioritize economic rationality over political rationality, rather the converse. I agree with Wildavsky, writing back in 1968 about the then fashionable management reform of PPBS (Planning, Programming, and Budgeting System), when he vigorously argued that 'political rationality is the fundamental kind of reason' it determines 'the decision structures [that] are the source of all decisions (Wildavsky 1968, 393). So, much government is not about strategy and priorities but the appearance of rule: 'about stability. Keeping things going, preventing anarchy, stopping society falling to bits. Still being here tomorrow' (Lynn and Jay 1984, 454). I do not seek, as did the authors of the quote, to make people laugh. In this witticism is much wisdom, not cynicism.

\section{$\underline{\text { Institutional memory, not internal structures }}$}

Reform all too frequently involves splitting up existing units, creating new units, redeploying staff, bringing in outsiders, revamping IT systems. A key unintended consequence is the loss of institutional memory. Pollitt (2007: 173) gives his recipe for eroding institutional memory: rotate staff rapidly, change the IT system frequently, restructure every two years, reward management over other skills, and adopt each new management fad. All three departments met 
most of these criteria. There was a tacit policy of depleting a proven asset for unproven gains. Institutional memory is the source of stories; the department's folk psychology, providing the everyday theory and shared languages for storytelling. These stories involve a retelling of yesterday to make sense of today. They explain past practice and events and justify recommendations for the future. It is crucial if the civil service is to tell accurate and reliable stories.

Of course, there is some awareness of the importance of some everyday routines. The BGI (2010) report, written by senior officials, considers that Ministers and civil servants can move too often between jobs and subject areas. As a result, 'records of previous decisions or past events may no longer exist or be easily available ... [and there] ... has been a serious weakening of corporate memory with the risk of failure in strategy, policy and delivery'. It calls for 'special attention ... to the maintenance, preservation and accessibility of departmental records (BGI 2010, 35, 36 and 41; see also PASC 2011c, 13-14). But such suggestions are the exception not the rule

\section{Storytelling, not evidence based policy}

Storytelling substitutes plausible conjecture for prediction. It does not exclude rational policy analysis. It treats it simply as another way of telling a story alongside all the other stories in a department. So, stories are modest in their claims. Each story is one set of spectacles for looking at the world (see, for example, Boje 1991; Czarniawska 2004; Gabriel 2000; and Weick 1995).

How can you tell which story makes the most sense? The short answer is that the civil service has been doing it for years. So, they identify and construct the story line by asking 'what happened and why?' They also ask whether a story is defensible (to both internal and external audiences); accurate (in that it is consistent with known and agreed 'facts'), 
believable (in that it is consistent with the departmental philosophy). Lying is seen as a worse sin than error, accident, even incompetence. So, they test 'facts' in committee meetings and rehearse story lines or explanations to see what they sound like and whether there is agreement. They judge how a story will play publicly by the reactions of their colleagues. In this way, they can anticipate the reaction of an external audience. They compare stories in the same way.

\section{Contending traditions and stories, not just managerialism}

Even today, ministers and civil servants act as if the nineteenth century liberal constitution sets the rules of the political game. The British constitution reminds me of geological strata, a metaphor which captures the longevity of the beliefs and practices. I do not want to suggest that nothing has changed. Obviously much has changed, but much remains. Managerialism and network governance have not replaced earlier beliefs and practices; rather, they coexist with the inherited Westminster tradition. Ministers and civil servants are fluent in all these languages, yet they continue to act as if earlier constitutional beliefs and practices are reliable guides for presentday behaviour. So, my big surprise was that British government was riven with incommensurable traditions and their stories. There was no agreed standard for comparing the stories. Even within a government department, let alone across central government, there was no shared story of how British government worked. Yesterday's story remained an important guide to today's practice. So, the managerial story (in its various forms) and the governance stories have not replaced the Westminster tradition.

Elite actors displayed variable interest or concern in resolving such dilemmas. For example, ministers and civil servants have overlapping roles and responsibilities. Typically, would-be reformers want to clarify the constitutional relationship between ministers and civil 
servants. They want to spell out roles and relationships. For example, the PASC $(2011,29)$ argued:

The convention of ministerial responsibility ... derived from the Haldane Report at the beginning of the last century have, on the whole, stood the test of time. However ... it is timely to consider the development of a new Haldane model to codify the changing accountabilities and organization of government.

But, typically, ministers and their civil servants have a vested interest in the current arrangements. Its ambiguity protects them from effective scrutiny. Thus, the Government's response to the PASC recommendations was dismissive, brusquely referring the Committee to "the statutory position of civil servants whose accountability is to Ministers who in turn are accountable to Parliament' (PASC 2012, 12). Haldane prevails because it serves the interests of both Ministers and their civil servants. And yet the Government proclaims, 'the old idea of a Civil Service "generalist" is dead'. Instead, they say they want 'the right combination of professionalism, expert skills and subject matter expertise' (Cabinet Office 2012, 23). Where are the political antennae that point out the hole to the minister before he or she falls in? Where are the political skills that pull him or her out of the hole afterwards, and argue that he or she never fell in? Have would-be reformers persuaded ministerial colleagues to forsake the cocoon of willed ordinariness at the top of departments that exists to protect the minister? Private offices exist to domesticate trouble, to defuse problems, and to take the emotion out of a crisis. Protocols are the key to managing this pressurized existence. Everyday routines are unquestioned and unrecognized. The reformers know not what they seek to reform.

Similarly, managerial reform is all too often a secondary concern for Ministers and their civil servants. I agree that effective performance measurement needs more clarity if performance management is what matters. My problem is that, when I imagine myself in a minister's or 
permanent secretary's shoes, performance management does not seem to matter that much. Useful, but not where the real action is. Ministers are not managers. It is not why they went into politics. A minority of Secretaries of State take an interest, even fewer Ministers of State. These brute facts undermine reform. The civil service exists to give ministers what they want and most do not want anything to do with management reform. At best, it is not a priority. At worst, it is not even on the radar.

\section{The politics of implementation, not top-down innovation and control}

Politics and policies do not arise exclusively from the strategies and interactions of elites. Other actors can resist, transform, and thwart the agendas of elites. An anthropological approach draws attention to the diverse traditions and narratives that inform actions at lower levels of the hierarchy, and the actions of citizens. For example, we know street-level bureaucrats shape service delivery in crucial ways. They use local knowledge and local reasoning to decide what policy will be for clients (see Maynard-Moody and Musheno 2003). In a similar vein, Lindblom (1990) compares professional with lay knowledge to the discomfort of the former. Understandings of how things work around here are embedded not only in the taken for granted routines and rituals of the departmental court but also the beliefs and practices of actors at lower levels of the hierarchy. Not only is such knowledge rarely part of the policy process, it is not valued. Yet it is often crucial to the success of policies especially in their implementation. Although one strand in the British political tradition asserts that 'leaders know best', the track record of much top-down innovation and control does not inspire confidence.

Moreover, when implementation is part of government thinking, it is strangely divorced from everyday knowledge. Thus, the Civil Service Reform Plan (Cabinet Office 2012, chapter 3) adopts the top-down, rational model of implementation with its imperatives 
for clear objectives, robust management information, and project management. If social science research ever teaches us anything, it tells us that the top-down model is plagued with implementation deficits (see O’Toole 2000; Pressman and Wildavsky 1984; and Sabatier 1986). Curiouser and curiouser, the report states that 'much of this failure has been because policy gets announced before implementation has been fully thought through' $(2012,18)$. From this statement, do we conclude that ministers delay their history making policy announcements while their civil servants spot snags? Ministers have short tenure. They will not sit around waiting on what they see as mere detail. Probably, they will not be there when the implementation problems arrive. Snag spotting irritates them (Rhodes 2011, 185). Civil servants are wary of speaking too much truth to power. Even more of a problem, the statement also assumes that civil servants are responsible for implementation when many departments rely on third parties. They have a hands-off, not hands on, link to policy implementation. As Bovens $(1998,46)$ puts it, they confront the "the problem of many hands" where responsibility for policy is shared. Everyday lay knowledge would tell policy makers about the limits to implementation, but no one would be listening.

\section{Dilemmas, languages and storytelling}

What would a reform strategy informed by my analysis look like? There are three points of intervention focused on the disconnections between dilemmas, languages and stories.

British government comprises several contending traditions, which have been grafted on to the Westminster tradition. Westminster, managerial and governance traditions co-exist side by side with all the attendant dilemmas. Reform should focus on the dilemmas. We need to find out whether different sections of the elite draw on different traditions to construct different narratives about the world, their place within it, and their interests and values. Both 
the diversity and common ground need to be specified, not taken for granted or ignored. We need to specify the opportunities for, and obstacles to change; otherwise reform will be dogged with misfortune from the moment it starts. Such an approach favours incremental change over more ambitious schemes and gives a distinctive twist to 'what works'.

The several traditions use distinct and distinctive languages. Westminster itself has the classic liberal terminology streaked with the colonialism and class languages of yesteryear such as chaps and Sherpa's. There is the ever-present gobbledygook of acronyms. Managerialism has three main dialects; performance management, marketization, and delivery. Outsiders import new languages. Think-tanks, management consultants and professional experts (inside and outside the civil service) provide specialist advice in their preferred professional language. Special Advisers (SpAds) provide the party political language. When and where are the different languages used? The choice of language is not incidental or neutral. Westminster aspires to be the lingua franca. It is the central stream. Other languages remain in play to the point of ministerial decision; they are the tributaries. The Westminster language symbolises the constitutional verities and sustains the central role of minister and permanent secretary. This primacy means that critics of the civil service for the slow pace of change attack the wrong target. They should look instead to ministers as the main wellspring of change in British government As long as ministers are in the spotlight for civil servants, they will give priority to sustaining the cocoon and willed ordinariness.

Storytelling is not an example of academic whimsy. It is an everyday practice. The challenge is to get the departmental court to wear night vision spectacles to identify and collect the many, relevant and sometimes unheard stories. At the heart of a storytelling approach would be collecting the several voices in the department stories and increasing the voices heard. The second step would be to develop transparent criteria for writing, evaluating and comparing stories. Currently, such criteria are embedded in words like 'sound', 
'judgement', 'experience' and 'safe pair of hands'. They communicate understood, shared but tacit meanings.

When collecting the several voices, the focus will be on everyday knowledge; on institutional memory and the limits to implementation. Institutional memory provides the everyday theory and shared languages for storytelling. It is the knowledge base of snag spotting. Ministers are schizophrenic about it. They complain about both the loss of institutional memory and about snag spotting. Both are central to an effective civil service yet I am not aware of any official actions to preserve and enhance institutional memory. Similarly, despite calls by the Coalition for more effective implementation, there is nary a mention of lay knowledge. The beliefs and practices of actors at lower levels of the hierarchy are not deemed important for the policy process. The political-administrative elite know best. The rational model is the favoured way of legitimating decisions. So, lay knowledge is sidelined despite the obvious limits of many top-down reforms. Effective reform hinges on legitimating lay knowledge; on accepting the inevitable influence of folk theories.

Indubitably, the lessons of my fieldwork are not the basis of conventional reform proposals. My portrait of a storytelling political-administrative elite with beliefs and practices rooted in the Westminster model that uses protocols and rituals to domesticate rude surprises and recurrent dilemmas is not the conventional portrait and it is the antithesis of the instrumental rationality of evidence-based policymaking, managerialism, and choice. The key task in civil service reform is to steer other actors using storytelling. Storytelling organizes dialogues, foster meanings, beliefs, and identities among the relevant actor. It seeks to influence what actors think and do, and foster a shared narrative of change. It is about continuities and preserving the departmental philosophy and its everyday folk theories and shared languages that enable a retelling of yesterday to make sense of today. 


\section{PROSPECTS}

What are the strengths and weaknesses of the storytelling, ethnographic approach in the study of public administration? What do we know from my story that we don't know from Yes Minister and the existing public administration and political science literature? The approach has several strengths.

First, it takes the webs of meanings of actors as its basic building blocks. For example, there is much agreement in the academic literature that the constitution is in disarray (see, for example, Bogdanor 2003; and King 2007). There is much to agree about in these several critiques of the constitution and constitutional reform. Yet ministers and civil servants act as if the old verities are constant; for example, they believe they are accountable to Parliament and act accordingly. My approach provides an actor-centred account of British government. I focus on the social construction of practices through the ability of individuals to create, and act on, meanings. I unpack practices as the disparate and contingent beliefs and actions of individuals.

Second, the approach focuses on diversity. For example, I do not privilege any one tradition but treat them all as living and contending traditions. No one account is comprehensive. Each web of inherited beliefs and practices shapes some ministerial and civil servant actions. Each explains some actions by some people some of the time. Similarly, each tradition has its own language, often with dialects. Whitehall is polyglot. Top civil servants are multilingual, combining Westminster, managerial, professional, political, and networking languages. This diversity undermines any reforms that assume one size fits all. 
Third, the analysis of the dilemmas posed by the diverse traditions highlights how new ideas produce not only change but also resistance. To twist a familiar saying, 'you can change if you want but this practice is not for changing'. Indeed, it is the embedding of yesterday's beliefs in today's protocols and rituals that makes change such a hazardous enterprise.

Fourth, the ethnographic approach admits of surprises. As with much ethnography, it looks for the hidden and the inaccessible, so there are moments of epiphany that open new research agendas. It accepts serendipity and happenstance. In this article, the surprises included the persistence of the nineteenth century liberal constitution and the commonplace use of storytelling.

Fifth, the approach helps to analyse the symbolic dimensions of political action. Most political behaviour has a strong symbolic dimension. Symbols do not simply 'represent' or reflect political 'reality', they actively constitute that reality. By drawing out the negotiated, symbolic and ritual elements of political life, ethnographic analysis draws attention to deeper principles of organization that are not visible to empiricist or positivist approaches. Thus, ministers are heirs to a royal tradition and it shows in the present-day practices, especially in the appearance of rule.

Finally, this approach does not privilege managerial rationality or the preferences of managers. Rather, it focuses on the manifold stories of government departments. It seeks to give voice to the forgotten in the reform literature. The focus is local, micro and actual (Aronoff and Kubik 2013, 25).

\section{LIMITS}


What are the limits of such an approach for the reform of public administration? Playing the role of 'social technologists' and using observational fieldwork to produce proposals for civil service reform poses several problems. I consider them under the headings of: roles, relevance, time, evidence, and working with elites (see also Agar 1996; Kedia and Willigen 2005; Rhodes et al 2007; Sillitoe 2006; and Van Willigen 2002).

There is no agreement on the role of the anthropologist let alone on whether anthropology should be 'relevant' and how that could be achieved. Van Maanen (1978, 3456) describes his relationship with the police he was observing as: 'a cop buff, a writer of books, an intruder, a student, a survey researcher, a management specialist, a friend, an ally, an asshole, a historian, a recruit and so on'. He was 'part spy, part voyeur, part fan and part member'. Similarly, Kedia and Van Willigen $(2005,11)$ distinguish between 'policy researcher or research analyst; evaluator; impact assessor, or needs assessor; cultural broker; public participation specialist; and administrator or manager'. Applied anthropology can serve many masters.

For Van Willigen applied anthropology is about providing information for decision makers so they can make rational decisions. Or, more formally, applied anthropology is a 'complex of related, research-based, instrumental methods which produce change or stability in specific cultural systems through the provision of data, initiation of direct action, and/or the formulation of policy' (Van Willigen (2002, 150 and chapter 10). Not everyone would agree that the task is to help decision makers. For Agar (1996, 27), 'no understanding of a world is valid without representation of those members' voices'. For him, 'ethnography is populist to the core' and the task is to be 'sceptical of the distant institutions that control local people's lives'. 
Managers are scarcely sympathetic to such aims. They see anthropologists as 'coming forward with awkward observations' and 'as wishing to preserve "traditional" ways' (Sillitoe 2006, 10). Managers criticise anthropologists because their findings often failed to conform to expectations held by employers about the causes of problems and their solutions'. They were dismissed as 'irrelevant or disruptive' (Sillitoe 2006, 14). As Kedia and Van Willigen (2005, 16-20) observe, applied anthropology confronts an acute and recurring moral dilemma 'since the practitioner must negotiate an intricate balance between the interests of the clients who commission the work, and those of the community being studied'. Inevitably, there are issues about whose aims are served by the research, who owns the research results, and individual privacy. Given that observational fieldwork is about decentring an established organization to identify its several voices, its contending beliefs and practices, and its traditions and stories (Bevir and Rhodes 2006), then the research is never about privileging any one voice. From the viewpoint of the managers, therefore, there is always the potential for disruption and irrelevance.

Given managerial concerns about such anthropological decentring and disruption, it is ironic that my political science colleagues express concern about its conservative outlook. In effect, they claim that by describing life at the top, I justify it. I am too sympathetic to ministers 'bleating about their world as one of high risk and shock' and I seek to 'make the life of the political administrative class more comfortable'. I agree description can spill over into justification and, therefore, seem conservative but that is not my intention. My aim is to understand, not sympathize. I want would-be reformers to be aware of the likely pitfalls; that is, to know what they are seeking to reform. After all, the reformers have had the field to themselves for decades with, at best, modest success. I am explaining why that success is modest. Reformers who advocate evidence-based policy making need to draw on observational evidence in designing change. It is conspicuous for its absence. Ministers bleat 
for reforms which they then do little to support. A key part of the inertia is not the civil service but the politicians, and reformers will continue to see their reforms fail because they continue to target the civil service.

The claim to relevance is further compounded by the problem of time. Observation in the field is time consuming and fits uncomfortably if at all with the demands of politicians and administrators alike. The brutal fact is that if you want to understand everyday life you have to stick around, go where you are led, and take what you are given. The Minister and the department will not wait on the results from such unstructured soaking. Of course, fieldwork does not have to be the decade long immersion of the lone researcher. There are shortcuts; for example, by using teams of fieldworkers, collaborative working with the client, snapshots across locations and time, and storytelling circles (Czarniawska, 2004, chapter 3). But getting below and behind the surface of official accounts to provide texture, depth and nuance and opening the consciousness of one group of people to another (Geertz 1988) cannot be done overnight. I was lucky - the civil service agreed to my doing 'curiosity research'.

Finally, there is the delicate issue of managing relationships with the elite. I have considered this at length elsewhere (Rhodes et al 2007, chapter 9) but two points bear repetition. I was not studying the powerless. Rather, the research 'subjects' were more powerful than me. They can, and a minority did, refuse interviews, deny access to the organization, declare documents secret, and insist on anonymity for both themselves and their organization. All the interviews and periods of observation took place with informed consent but as the work unfolded I had to negotiate constantly to keep that cooperation. Also, it is all too easy to affect the relationship between yourself and the observed, causing them to behave differently. The aim of the so-called 'non-participant' observer is to remain the outsider; 'the professional stranger' (Agar 1996). However, for lengthy on-site visits and extensive repeat 
interviews, you have to have a conversation and engage with the people around you. You have to establish rapport. You are sucked into events, even if it is only casual badinage to ease tension. For example, one permanent secretary gave me a copy of his diaries. The analysis of his engagements and committee work showed he was spending about one-third of his time on corporate civil service business outside the department. He was surprised. He had no clear picture of the distribution of his workload. Immediately, he began to reduce his corporate commitments. He could exercise much control over his working life, and he knew it. My example makes it clear that the powerful are different. They can shape your research and change everyday life even as you look at it.

\section{CONCLUSIONS}

In political science, the dominant tradition is modernist-empiricism with its roots in the natural science model. The argument about blurred genres takes as its starting point the turning away from that model and the idea of law-like generalizations. As Inglis $(2000,112)$ argues, there has been a lethal attack on modernist-empiricism, and the work of philosophers such as Charles Taylor, Peter Winch and Alasdair McIntyre means that using the methods of the natural sciences in the human sciences is 'comically improper'. Richard Bernstein, Clifford Geertz, and Richard Rorty could be added to a long and growing list of such critics, before mentioning the long-standing hermeneutics tradition of Continental Europe. This 'interpretive turn' raises the problem of what counts as evidence. It might seem obvious that 'not everything that counts can be counted, and not everything that can be counted counts' (sign hanging in Albert Einstein's office at Princeton), but not when it comes to civil service reform and policy analysis. It is a world of given facts, positive theory and hypothesis testing. Qualitative data simply does not meet these expectations because it does not count as 
generalizable evidence. My observational data is evidence as relevant to civil service reform as the evidence conventionally used to support managerialism.

The attempts to impose private sector management beliefs and techniques to increase the economy, efficiency and effectiveness resulted in the civil service reform syndrome. If private sector techniques offer such obvious and available ways to manage, then why is so little implemented across government? It is not because public managers are ill-trained, stupid or venal, but because private sector techniques do not fit the context. Such techniques can be neutered by both bureaucratic and political games, and are subjected to public accountability. Public sector officials also do not share the same risks and rewards. Similarly, rational meansends analysis is largely removed from the reality of public policy making. Politics, value clashes, interests, cultures, symbolic imperatives, processes and accountability requirements all make the rational actor model untenable in public policy decision-making. Internal reorganization has marginal effects on beliefs, practices and traditions. Chanting the mantras of organizational change and leadership leaves most of the organization untouched. The choice agenda ignores the political context confronting ministers and senior civil servants. 'Hands off' advice is an anathema to the British governing elite that has always known best.

The rational, managerial approach has predominated since 1968, producing little beyond the civil service reform syndrome. We do not need more of the same. We need a different approach to reform. The storytelling approach is a contender. A bottom-up approach to reform rooted in the everyday knowledge of departments is a lone voice in this wilderness, but it can hardly do worse. It holds out the prospect of reforms that command legitimacy at lower levels of the bureaucracy even if they do not directly serve the interests of ministers and permanent secretaries. Therein lies the rub. We must never forget that civil service reform is 
about the constitutional and political role of public administration in the polity; it is not about better management. 


\section{REFERENCES}

Agar, M. 1996. The Professional Stranger. Second edition. San Diego: Academic Press.

Aronoff, M. J. and Kubik, J. 2013. Anthropology and Political Science. A Convergent Approach. New York: Berghahn Books.

Argyris, C. and Schon D. 1996. Organizational Learning II: a Theory of Action Perspective. Reading, Mass.: Addison-Wesley.

Barber, Michael 2007. Instruction to deliver. Tony Blair, public services and the challenge of targets. London: Politico's.

Better Government Institute 2010. Good Government. Reforming Parliament and the Executive. Recommendations from the Executive Committee of the Better Government Initiative.

Bevir, M. and Rhodes, R. A. W. 2006. Governance Stories. Abingdon, Oxon: Routledge. Blair, Tony 2004. Speech on modernisation of the Civil Service. 24 February. See Tony Blair archive @: http://www.number10.gov.uk/Page5399. Last accessed 6 October 2009.

Bogdanor, V. (Ed.) 2003. The British constitution in the twentieth century. Oxford: Oxford University Press for the British Academy.

Boje, D. 1991. 'The Storytelling Organization: A Story of Story Performance in an OfficeSupply Form', Administrative Science Quarterly 36 (1): 106-26.

Bourdon, R. 1993. 'Towards a Synthetic Theory of Rationality', International Studies in the Philosophy of Science 7 (1): 5-19. 
Bovens, M. 1998. The Quest for Responsibility: Accountability and Citizenship in Complex Organizations. Cambridge: Cambridge University Press.

Bullock, H., Mountford, J. and Stanley, R. 2001. Better Policy Making. London: Centre for Management and Policy Studies (CMPS).

Cabinet Office 1999. Professional Policy Making for the Twenty-First Century. London: Cabinet Office.

Cabinet Office 2012. The Civil Service Reform Plan. London: Cabinet Office 2012.

Cameron, David 2011. 'Speech on Open Public Services', 11 ${ }^{\text {th }}$ July. Available @: http://www.number10.gov.uk/news/speech-on-open-public-services/ Last accessed 31 July 2012.

Cm 8145. 2011. Open Public Services White Paper. London: Stationary Office.

Common, R. 2004. 'Organisational Learning in a Political Environment: Improving PolicyMaking in UK Government', Policy Studies 25 (1): 35-49.

Czarniawska, B. 2004. Narratives in social science research. London: Sage.

Davies, Huw T. O., Sandra M. Nutley and Peter C. Smith (Eds.), 2000. What Works? Evidence-based Policy and Practice in Public Services. Bristol: The Policy Press.

Fine, G. A., C. Morrill and S. Surianarain 2009. 'Ethnography in Organizational Settings'. In D. Buchanan and A. Bryman (Eds.), Handbook of Organizational Research Methods. London: Sage: 602-19.

Gabriel, Y. 2000. Storytelling in Organizations. Facts, Fictions and Fantasies. Oxford: Oxford University Press. 
Geertz, C. 1983. 'Blurred Genres. The Refiguration of Social Thought', in his Local Knowledge. Further Essays in Interpretive Anthropology. New York: Basic Books: 19-35.

Geertz, C. 1988. Works and Lives: the Anthropologist as Author. Stanford: Stanford University Press.

Geertz, C. 1993 [1973]. 'Thick Descriptions: Towards an Interpretive Theory of Culture', in his The Interpretation of Cultures. London: Fontana: 3-30.

Hood, Christopher and Lodge, Martin 2007. 'Endpiece: Civil Service Reform Syndrome - Are We Heading for a Cure?' Transformation, Spring, 58-59.

Inglis, F. 2000. Clifford Geertz. Culture, Custom and Ethics. Oxford: Blackwell.

Institute for Government 2010. Shaping-Up: A Whitehall for the Future. London: Institute for Government.

Kedia, Satish, and Willigen J. Van 2005. 'Applied Anthropology: Context for Domains of Application', in Kedia, Satish, and Willigen J. Van, (Eds.), Applied Anthropology: Domains of Application. Westport, Conn: Praeger: 1-32.

King, A. 2007. The British Constitution. Oxford: Oxford University Press.

Law, J. 1994. 'Organization, Narrative and Strategy'. In J. Hassard and M. Parker (Eds.), Towards a New Theory of Organizations. London: Routledge: 248-68.

Lindblom, C. E. 1990. Inquiry and change. New Haven: Yale University Press.

Lodge, G. and Rogers, B. 2006. Whitehall's Black Box. Accountability and Performance in the Senior Civil Service. London: Institute for Public Policy Research 
Lynn, Jonathan and Jay, Anthony 1984. The Complete 'Yes Minister': The Diaries of a Cabinet Minister. London: BBC Books.

Maynard-Moody, S. and Musheno, M. 2003. Cops, Teachers, Counsellors: Stories from the Front Lines of Public Service. Ann Arbor, Michigan: The University of Michigan Press. Mulgan, G. 2009. The Art of Public Strategy. Mobilizing Power and Knowledge for the Common Good. Oxford: Oxford University Press.

National Audit Office (NAO), 2001. Modern Policy-Making: Ensuring Policies Deliver Value for Money, Report by the Comptroller and Auditor General, HC 289 Session 20012002:November 2001. London, National Audit Office.

Oakeshott, M. 1996. The Politics of Faith and the Politics of Scepticism. Edited by Timothy Fuller. New Haven: Yale University Press.

O’Donnell, Sir Gus 2012. 'Ten Commandments of Good Policy Making: A Retrospective'. Available @: http://blogs.lse.ac.uk/politicsandpolicy/2012/05/01/retrospective-sir-gusodonnell/. Last Accessed on $25^{\text {th }}$ July 2012.

O’Toole, L. 2000. 'Research on Policy Implementation: Assessment and Prospects.' Journal of Public Administration Research \& Theory 10 (2): 263-288.

Pollitt, C. 1993. Managerialism and the Public Services. Second edition. Oxford: Blackwell.

Pollitt, C. 2007. Time, Policy, Management. Governing with the Past. Oxford: Oxford University Press.

Pressman, J. and A. Wildavsky. 1984. Implementation: How Great Expectations In Washington Are Dashed In Oakland. Third edition. Berkeley: University of California Press. 
Public Administration Select Committee 2003. On Target? Government by Measurement. Volume 1. Report together with formal minutes. Fifth report, Session 2002-03, HC 62-1. London: Stationary Office.

Public Administration Select Committee 2005. Choice, voice and public services. Fourth report, Session 2003-04, HC 49-I. London: Stationery Office.

Public Administration Select Committee 2009. Good Government. Eighth Report, Session 2008-09, HC 97-1. London: Stationary Office.

Public Administration Select Committee 2011. Change in Government: the agenda for leadership. Thirteenth report, Sessions 2010-12, HC 714. London: Stationary Office.

Public Administration Select Committee 2012. Change in Government: the agenda for leadership: Further Report with the Government's response to the Committee's Eleventh, Thirteenth and Fifteen Reports of Session 2010-12. Eighteenth Report, Session 210-12, HC 1746. London: Stationary Office.

Regulatory Policy Institute 2009. Trust in the System: Restoring Trust in our System of Government and Regulation Oxford: Regulatory Policy Institute.

Rhodes, R. A. W. 2011. Everyday Life in British government. Oxford: Oxford University Press.

Rhodes, R. A. W. 2013. 'From Core Executive to Court Politics', in Paul Strangio, Paul ‘t Hart and James Walter, (Eds.), Prime Ministerial Leadership: power, party and performance in Westminster systems. Oxford University Press, forthcoming.

Rhodes, R. A. W., ‘t Hart, P. and Noordegraaf, M. (Eds.) 2007 Observing Government Elites: up close and personal. Houndmills, Basingstoke: Palgrave-Macmillan. 
Sabatier, P. 1986. 'Top-down and Bottom-Up Approaches to Implementation Research: A Critical Analysis and Suggested Synthesis.' Journal of Public Policy 6 (1): 21-48.

Sanderson, I. 2002. 'Evaluation, Policy Learning and Evidence Based Policy Making'. Public Administration 80 (1): 1-22.

Shore, C. and Wright, S. (Eds.) 1997. The Anthropology of Policy. Critical Perspectives on Governance and Power. London: Routledge.

Sillitoe, Paul. 2006. 'The Search for Relevance: A Brief History of Applied Anthropology'. History and Anthropology, 17 (1): 1-19.

Van Maanen, J. 1978. 'Epilogue: On Watching the Watchers'. In P. K. Manning and J. Van Maanen, (Eds.) Policing: A View from the Street. Santa Monica, Ca: Goodyear: 309-49.

Van Willigen, John 2002. Applied Anthropology: An Introduction. $3^{\text {rd }}$ Edition. Westport, CT: Bergin \& Garvey.

Weick, K. E. 1995. Sensemaking in Organizations. Thousand Oaks: Sage Publications.

Weiss, Carol H. 1980. 'Knowledge Creep and Decision Accretion', Science Communication 1 (1): 381-404.

Wildavsky, A. 1968. 'The Political Economy of Efficiency: Cost-Benefit Analysis, Systems Analysis and Program Budgeting'. In F. J. Lyden and E. G. Miller (Eds.), Planning Programming Budgeting: a Systems Approach to Management, Chicago: Markham: 371-402.

Wulff, H. 2002. 'Yo-Yo Fieldwork: Mobility and Time in Multi-Local Study of Dance in Ireland', Anthropological Journal of European Cultures 11: 117-36. 